\title{
Karyotypes of 3- or 4-day-old pig embryos after short in-vitro culture
}

\author{
F. A. van der Hoeven, M. P. Cuijpers and P. de Boer \\ Department of Genetics, Agricultural University, 53 Gen. Foulkesweg, 6703 BM Wageningen, \\ The Netherlands
}

\begin{abstract}
Summary. Pig embryos (3-4 days old) were grown for $\sim 21 \mathrm{~h}$ in microdroplets under mineral oil with vinblastin sulphate as the mitotic inhibitor. From 10 gilts, 115 eggs were cultured: 8 proved to be unfertilized oocytes, 9 did not contain mitotic figures, 16 contained fewer than 3 good mitotic figures and 80 were judged to be of normal karyotype. A few polyploid cells were encountered, possibly of trophoblast origin. One embryo was a haploid and another one a $2 \mathrm{~N} / 6 \mathrm{~N}$ mixoploid. In one gilt, in which there was no evidence of fertilization, a tetraploid embryo was discovered, and was assumed to be parthenogenetic.
\end{abstract}

\section{Introduction}

Interest in the chromosomal constitution of pronucleate zygotes, preimplantation embryos and abortion material of mammals stems from two sources: (a) the high levels of prenatal wastage that are recorded in man (Boué, Boué \& Lazar, 1975) and in farm animals (Hanly, 1961) and (b) the high frequency of chromosome abnormalities among human abortion material, with trisomies and polyploidies as the prevailing abnormalities (Boué et al., 1975). In man, there is a coincidence between a high level of chromosome abnormalities amongst early conceptuses and a high level of prenatal death. Experimental animals such as the mouse, the Syrian hamster and the rabbit are characterized by lower levels of embryonic wastage and the frequencies of chromosome abnormalities amongst pronucleate eggs and young blastocysts are also low (rabbit: Fechheimer \& Beatty, 1974; mouse: Fraser \& Maudlin, 1979; Syrian hamster: Martin, Balkan \& Burns, 1983).

The chromosomes of preimplantation embryos from chromosomally normal parents have been studied for 10-day-old pig blastocysts (McFeely, 1967; Dolch \& Chrisman, 1981; Long \& Williams, 1982), 12-18-day-old cow blastocysts (Hare et al., 1980) and 2-4-cell stages of sheep embryos (Long \& Williams, 1980). For the pig, the initial claim that chromosome abnormalities are very common among 10-day-old pig blastocysts (McFeely, 1967) has not been substantiated by subsequent research. In cattle, no abnormalities besides mosaicism with a polyploid cell line have been recorded (Hare et al., 1980; see also 'Discussion'). Aneuploid sheep embryos have been found at a frequency of $4 \cdot 7 \%$ (Long \& Williams, 1980).

For the pig, it is known that the preovulatory LH peak in the peripheral blood occurs with a wide margin relative to the onset of behavioural oestrus (Tilton, Foxcroft, Ziecik, Coombs \& Williams, 1982) and so the age of the conceptus cannot be given with the precision of one cell division. Furthermore, the division from 4 to 8 cells occurs with delay (Hunter, 1974). To circumvent these problems and to collect as many mitotic figures as possible in embryos that are as young as possible, we have chosen to sample 3-4-day-old pig morulae-blastocysts for chromosome analysis. Our results are compared with those of Long \& Williams (1982) to determine whether chromosome abnormalities in the pig, present at the morula and young blastocyst stages, are incompatible with embryonic survival until Day 10 or whether a genuinely low frequency of chromosome abnormalities exists in pig conceptuses. 


\section{Materials and Methods}

Dutch Landrace gilts (8-10 months old) were artificially inseminated on the first day of oestrus or on the subsequent day. Oestrus was detected by examination every $6 \mathrm{~h}$ with a teaser boar and gilts were inseminated the next day, or at 12:00 $\mathrm{h}$ on the same day if detected at the 07:00 h examination. The day of insemination was designated Day 1. The animals were slaughtered on Day 6 or 7 or hysterectomized on Day 6. If ovulation is assumed to take place $40 \mathrm{~h}$ after the onset of oestrus, the embryos recovered are in their 4th or 5th day of embryonic life, i.e. 3-4 days old. The uterine horns were flushed with Dulbecco's salt solution, made from tablets supplied by Oxoid Ltd (London, U.K.), to which was added $10 \mathrm{mg}$ polyvinylpyrrolidone $/ \mathrm{ml}$. The uterine horns were each flushed twice with $30 \mathrm{ml}$ fluid, from the body of the uterus towards the most cranial section of the uterine horns. All specimens found were cultured for $\sim 21 \mathrm{~h}$ in Whittingham's medium No. 16 (Whittingham, 1971) under mineral oil containing vinblastin sulphate (Velbe: Eli Lilly Benelux N.V., Brussels, Belgium: $0.005 \mu \mathrm{g} / \mathrm{ml}$ ) as the mitotic inhibitor and $12 \mathrm{mg}$ bovine serum albumin (BSA)/ml. Preparations were made using a modification of the technique of Tarkowski (1966). Usually, the embryos were not seen to dissociate in the first three drops of fixative (methanol/acetic acid, 3:1 v/v). Then, breakage of the zona pellucida was encouraged by blowing through a glass microcapillary after another drop of fixative had been applied. Zona breakage could be followed by the dispersion of yolk material over the slide. When this occurred, the slides were left to dry in air. Preparations were routinely stained with Giemsa for chromosome counting.

\section{Results}

Ten gilts contained developing embryos. Of a total of 138 corpora lutea, 118 embryos and unfertilized ova were recovered $(86 \%)$.

For 9 animals, Table 1 gives the results of the culture procedure (the mitotic indices) plus the cell counts at recovery, assuming the concentration of the spindle poison to be high enough to arrest all metaphases for the period of in-vitro culture. Of all embryos, $93 \%$ showed mitotic activity in culture. Four-day-old embryos tend to culture less well than 3-day-old embryos. Embryos at Day 5 from one gilt lost the zonae pellucidae in culture. As can be concluded from the standard deviations of the mitotic index, the success of the culture method was very variable but more so for the older embryos than for the younger ones. For the 3-day-old embryos, within-gilt standard deviations were smaller than between-gilt standard deviations ( 12.8 and 23 cells respectively). However, the 4-day-old embryos of the 3 gilts studied had a within-gilt standard deviation of $26 \cdot 6$ cells and a between-gilt standard deviation of 14.8 cells. More information about the differences between gilts with respect of the developmental stage of their embryos will be given in a subsequent paper, incorporating the hormonal patterns of early development in the pig (F. A. Helmond, unpublished results).

Of the 118 eggs recovered, 115 were subjected to culture. One was lost when making chromosome preparations. Eight eggs proved to be unfertilized oocytes of which 4 showed meiotic metaphase II chromosomes (Pl. 1, Fig. 4). In another 8 embryos no mitotic figures were present,

\section{PLATE 1}

Fig. 1. Normal chromosome complement of pig embryo $(2 \mathrm{~N}=38)$. Note the sperm head.

Fig. 2. Haploid chromosome complement.

Fig. 3. Nearly tetraploid chromosome complement.

Fig. 4. Degenerating chromosomes of the second meiotic division of the oocyte. 
PLATE 1

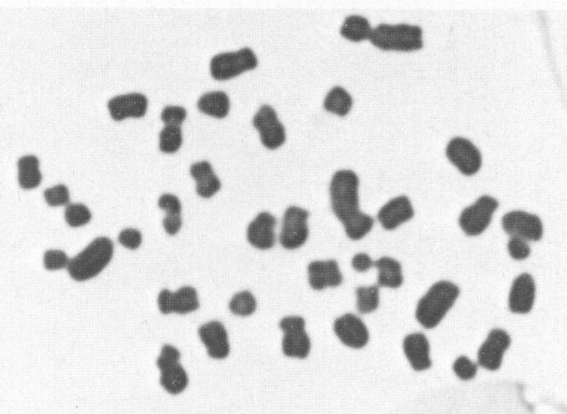

1

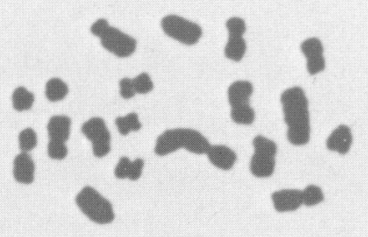

2

3
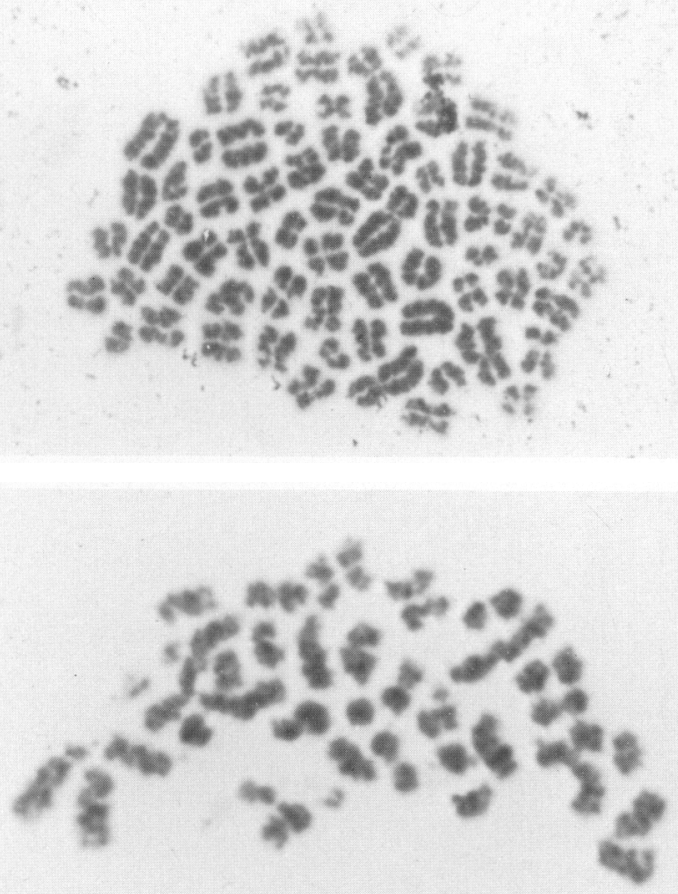

4

(facing p. 594) 
Table 1. Cell counts and mitotic indexes of the pig embryos that were used for karyotyping at two different calculated ages

\begin{tabular}{lcccc}
\hline $\begin{array}{l}\text { Embryo } \\
\text { age } \\
\text { (days) }\end{array}$ & Gilt no. & $\begin{array}{c}\text { No. of } \\
\text { embryos }\end{array}$ & $\begin{array}{c}\text { Cell number } \\
\text { (mean } \pm \text { s.d.) }\end{array}$ & $\begin{array}{c}\text { Mitotic index (\%) } \\
\text { (mean } \pm \text { s.d.) }\end{array}$ \\
\hline 3 & 173 & 6 & $9 \cdot 2 \pm 6 \cdot 2$ & $70 \cdot 4 \pm 29 \cdot 3$ \\
& 176 & 11 & $59 \cdot 9 \pm 22 \cdot 3$ & $51 \cdot 5 \pm 19 \cdot 8$ \\
& 177 & 15 & $63 \cdot 5 \pm 12 \cdot 4$ & $46 \cdot 7 \pm 20 \cdot 5$ \\
& ID & 4 & $8 \cdot 3 \pm 2 \cdot 9$ & $81 \cdot 9 \pm 28 \cdot 5$ \\
& 2D & 9 & $47 \cdot 9 \pm 6 \cdot 8$ & $57 \cdot 6 \pm 17 \cdot 5$ \\
& 162 & 11 & $12 \cdot 5 \pm 6 \cdot 4$ & $60 \cdot 9 \pm 42 \cdot 1$ \\
& Average & & $40 \cdot 5 \pm 26 \cdot 8$ & $56 \cdot 5 \pm 29 \cdot 2$ \\
\hline 4 & $33 Z$ & 13 & $52 \cdot 2 \pm 34 \cdot 4$ & $43 \cdot 7 \pm 31 \cdot 1$ \\
& & 16 & $72 \cdot 6 \pm 29 \cdot 9$ & $9 \cdot 3 \pm 6 \cdot 3$ \\
& $36 Z$ & 12 & $39 \cdot 9 \pm 10 \cdot 4$ & $20 \cdot 5 \pm 22 \cdot 0$ \\
& $44 Z$ & & $58 \cdot 2 \pm 29 \cdot 3$ & $23 \cdot 5 \pm 25 \cdot 6$ \\
\hline
\end{tabular}

whereas 16 embryos had fewer than 3 good quality mitotic figures. Amongst the resulting 82 embryos, 76 were $2 \mathrm{~N}$, containing 38 chromosomes, 3 were $2 \mathrm{~N} / 4 \mathrm{~N}, 1$ was a $2 \mathrm{~N} / 8 \mathrm{~N}$ mixoploid and 1 was $2 \mathrm{~N} / 6 \mathrm{~N}$ mixoploid. One other abnormality was detected as a haploid embryo consisting of 60 cells (litter mates had on average 63.5 cells) in which a Y-chromosome was lacking (Pl. 1, Fig. 2). All other eggs of this gilt were normal embryos and all specimens, including the haploid one, were surrounded by spermatozoa. We are inclined to think that this embryo was a parthenogenote but cannot exclude it being an androgenote or a gynogenote. In our experience, the presence of spermatozoa bound to the zona pellucida is a good indication for normal embryonic development, but not absolutely so (PI. 1, Fig. 1).

In the course of this project, we have encountered another 7 gilts in which the oocytes were considered to be unfertilized because of the absence of divisions and/or spermatozoa, and the morphological appearance (a shrunken and dark vitellus): 78 of these specimens were recovered $(80 \%$ recovery on the basis of the corpora lutea). Seven had some spermatozoa adhering to the zona pellucida and 8 still showed metaphase II chromosomes (Pl. 1, Fig. 4). One specimen from a gilt in which no association between spermatozoa and the zona pellucida was discovered in any of the oocytes found, contained 16 nuclei of which 3 were tetraploid or near-tetraploid mitotic figures (Pl. 2, Fig. 3). Parthenogenesis seems to be the most likely explanation for this embryo.

\section{Discussion}

In agreement with other authors (see Wright \& Bondioli, 1981, for review, pig embryos culture well in media that were originally designed for the culture of mouse embryos from the 1-cell stage to the blastocyst stage, but morphology of the pig embryos is improved by increasing the BSA content from 4 to $12 \mathrm{mg} / \mathrm{ml}$.

As shown in Table 1, there were large variations in the numbers of cells per embryo. At 3 days of calculated age, these were largely between-gilt differences. In agreement with Perry \& Rowlands (1962), these differences are attributable to gilt differences in the time of ovulation relative to the onset of oestrus (F. A. Helmond, unpublished results). From our results, it appears that embryos of around 50 cells (with a mitotic index of about $50 \%$ ) show the best results for chromosome analysis. The fact that we could not karyotype all the embryos is largely due to the variation of the oestrus-ovulation interval in naturally ovulating gilts. Of the non-euploid chromosome counts encountered, most occurred in $2 \mathrm{~N} / 4 \mathrm{~N}, 2 \mathrm{~N} / 8 \mathrm{~N}$ mixoploids. Thus a low frequency of $2 \mathrm{~N} / 4 \mathrm{~N}$ and 
$2 \mathrm{~N} / 8 \mathrm{~N}$ embryos occurred which is probably the result of endoreduplication in early differentiating trophoblast cells (Ansell, Barlow \& McLaren, 1974; Long \& Williams, 1982). The fact that at the beginning of blastulation, polyploid counts are less frequently encountered than when 10 days old embryos are analysed, supports the conclusion of Long \& Williams (1982) that polyploid lines from a mixoploid embryo originate from the differentiating trophoblast. The $2 \mathrm{~N} / 6 \mathrm{~N}$ embryo encountered so far is an exception in that the $3 \mathrm{~N}$ precursor cell of the $6 \mathrm{~N}$ one originates from another type of event. Fechheimer \& Beatty (1974) and Hare et al. (1980) report the occurrence of this type of embryo in the rabbit and cow respectively. Fechheimer \& Beatty (1974) and Hare \& Singh (1979) give modes of origin of this abnormality. The fact that Hare et al. (1980) did not obtain pregnancy after transfer of this type of embryo to pseudopregnant cattle does not prove the karyotype to be an embryonic lethal. As with artificial $2 \mathrm{~N} / 4 \mathrm{~N}$ mixoploids in the mouse (Tarkowski, Witkowska \& Opas, 1977), the $2 \mathrm{~N}$ component of the embryo proper can easily outgrow the $3 \mathrm{~N}$ component. Therefore, of all 'chromosome abnormalities' found, only the 'parthenogenetic' specimens seem to be embryonic lethals, both by the fact of their deviant karyotypes and by their probably parthenogenetic status. The haploid embryo encountered was not retarded in growth and had a very high mitotic index (73\%). Haploid mouse embryos arrived at through removal of the male pronucleus (Modlinski, 1975) and after parthenogenetic stimulation (see Whittingham, 1980, for review) show a reduced rate of cleavage. Probably genome expression after fertilization/ activation develops at a slower rate in the pig embryo, which is yolk-rich, than in the more translucent mouse embryo in which the genes switch on during the 2-cell stage (Magnuson \& Epstein, 1981).

It was already known that the frequency of chromosome abnormalities is low amongst a sample of 10-day-old pig blastocysts (Dolch \& Chrisman, 1981; Long \& Williams, 1982). The present report confirms these findings for a stage when real embryonic growth (after hatching from the zona pellucida) has not yet taken place. Thus, with respect to the aetiology of embryonic death, pigs resemble the experimental rodents more than they resemble man.

This project was carried out as part of the research of the working party "Early Pregnancy" from the Agricultural University, Wageningen. We thank the members of this party for their comments on the manuscript; Dr K. van Hellemond for surgical assistance; and Henk Stormink and Petra van Oosterbosch for their assistance with the embryos in this laboratory.

\section{References}

Ansell, J.D., Barlow, P.W. \& McLaren, A. (1974) Binucleate and polyploid cells in the decidua of the mouse. J. Embryol. exp. Morph. 31, 223-227.

Boué, J., Boué, A. \& Lazar, P. (1975) The epidemiology of human spontaneous abortions with chromosomal anomalies. In Ageing Gametes, their Biology and Pathology, pp. $330-348$. Ed. R. J. Blandau. S. Karger, Basel.

Dolch, K.M. \& Chrisman, C.L. (1981) Cytogenetic analysis of preimplantation blastocysts from prepuberal gilts treated with gonadotropins. Am. J. vet. Res. 42, 344-346.

Fechheimer, N.S. \& Beatty, R.A. (1974) Chromosomal abnormalities and sex ratio in rabbit blastocysts. $J$. Reprod. Fert. 37, 331-341.

Fraser, L.R. \& Maudlin, I. (1979) The anaylsis of aneuploidy in first-cleavage mouse embryos fertilized in vitro and in vivo. Environmental Heath Perspectives 31, 14l-149.
Hanly, S. (1961) Prenatal mortality in farm animals. $J$. Reprod. Fert. 2, 182-194.

Hare, W.C.D. \& Singh, E.L. (1979) Cytogenetics in Animal Reproduction. Commonwealth Agricultural Bureaux, Slough, U.K.

Hare, W.C.D., Singh, E.L., Betteridge, K.J., Eaglesome, M.D., Randall, G.C.B., Mitchell, D., Bilton, R.J. \& Trounson, A.O. (1980) Chromosomal analysis of 159 bovine embryos, collected 12 to 18 days after estrus. Can. J. Genet. Cytol. 22, 615-626.

Hunter, R.H.F. (1974) Chronological and cytological details of fertilization in early embryonic development in the domestic pig. Anat. Rec. 178, 169-185.

Long, S.E. \& Williams, C.V. (1980) Frequency of chromosomal abnormalities in early embryos of the domestic sheep (Ovis aries). J. Reprod. Fert. 58, 197-201.

Long, S.E. \& Williams, C.V. (1982) A comparison of the chromosome complement of inner cell mass and 
trophoblast cells in Day-10 pig embryos. $J$. Reprod. Fert. 66, 645-648.

Magnuson, T. \& Epstein, C.J. (1981) Genetic control of very early mammalian development. Biol. Rev. 56, 469-508.

Martin, R.H., Balkan, W. \& Burns, K. (1983) Cytogenetic analysis of Q-banded pronuclear chromosomes in fertilized Syrian hamster eggs. Cytogenet. Cell Genet. 35, $41-45$.

MeFeely, R.A. (1967) Chromosome abnormalities in early embryos of the pig. J. Reprod. Fert. 13, 579-581.

Modlinski, J.A. (1975) Haploid mouse embryos obtained by microsurgical removal of one pronucleus. $J$. Embryol. exp. Morph. 33, 897-905.

Perry, J.S. \& Rowlands, I.W. (1962) Early pregnancy in the pig. J. Reprod. Fert. 4, 175-188.

Tarkowski, A.K. (1966) An air-drying method for chromosome preparations from mouse eggs. Cytogenetics 5, 394400 .
Tarkowski, A.K., Witkowska, A. \& Opas, J. (1977) Development of cytochalasin produced tetraploid and diploid/tetraploid mosaic mouse embryos. $J$. Embryol. exp. Morph. 41, 47-64.

Tilton, J.E., Foxcroft, G.R., Ziecik, A.J. Coombs, S.L. \& Williams, G.L. (1982) Time of the preovulatory LH surge in the gilt and sow relative to the onset of behavioral estrus. Theriogenology 18, 227-237.

Whittingham, D.G. (1971) Culture of mouse ova. $J$. Reprod. Fert., Suppl. 14, 7-21.

Whittingham, D.G. (1980) Parthenogenesis in mammals. Oxf. Rev. Reprod. Biol. 2, 205231.

Wright, R.W. \& Bondioli, K.W. (1981) Aspects of in vitro fertilization and embryo culture in domestic animals. J. Anim. Sci. 53, 709-729.

Received 15 April 1985 